\title{
Effects of Orexin B on Swine Granulosa and Endothelial Cells
}

\author{
Francesca Grasselli ${ }^{1}$, Simona Bussolati ${ }^{1}$, Stefano Grolli ${ }^{1}\left(\mathbb{D}\right.$, Rosanna Di Lecce $^{1}$, Cecilia Dall'Aglio ${ }^{2} \mathbb{D}$ and \\ Giuseppina Basini ${ }^{1, *(D)}$
}

1 Dipartimento di Scienze Medico-Veterinarie, Università degli Studi di Parma, Via del Taglio 10, 43126 Parma, Italy; francesca.grasselli@unipr.it (F.G.); simona.bussolati@unipr.it (S.B.); stefano.grolli@unipr.it (S.G.); rosanna.dilecce@unipr.it (R.D.L.)

2 Dipartimento di Medicina Veterinaria, Università degli Studi di Perugia, Via San Costanzo 4, 06126 Perugia, Italy; cecilia.dallaglio@unipg.it

* Correspondence: basini@unipr.it; Tel.: +39-521-032-775

check for updates

Citation: Grasselli, F.; Bussolati, S.; Grolli, S.; Di Lecce, R.; Dall'Aglio, C.; Basini, G. Effects of Orexin B on Swine Granulosa and Endothelial Cells. Animals 2021, 11, 1812. https:// doi.org/10.3390/ani11061812

Academic Editor: Roy

Neville Kirkwood

Received: 6 May 2021

Accepted: 15 June 2021

Published: 17 June 2021

Publisher's Note: MDPI stays neutral with regard to jurisdictional claims in published maps and institutional affiliations.

Copyright: (c) 2021 by the authors. Licensee MDPI, Basel, Switzerland. This article is an open access article distributed under the terms and conditions of the Creative Commons Attribution (CC BY) license (https:/ / creativecommons.org/licenses/by/ $4.0 /)$.
Simple Summary: The follicle is the ovarian functional unit. It is mainly composed of granulosa cells and angiogenesis is crucial to guarantee its development till ovulation. Carrying on our previous studies on the orexin system in the ovary, we presently demonstrate a potential role of orexin B in the control of granulosa cells' oxidative stress and of the angiogenesis event.

Abstract: In addition to the well-known central modulatory role of orexins, we recently demonstrated a peripheral involvement in swine granulosa cells for orexin A and in adipose tissue for orexin B (OXB). The aim of present research was to verify immunolocalization of OXB and its potential role in modulating the main features of swine granulosa cells. In particular, we explored the effects on granulosa cell proliferation (through the incorporation of bromodeoxyuridine), cell metabolic activity (as indirect evaluation by the assessment of ATP), steroidogenic activity (by immunoenzymatic examination) and redox status (evaluating the production of superoxide anion by means of the WST test, production of nitric oxide through the use of the Griess test and the non-enzymatic reducing power by FRAP test). Our data point out that OXB does not modify granulosa cell growth, steroidogenesis and superoxide anion generation. On the contrary, the peptide stimulates $(p<0.05)$ nitric oxide output and non-enzymatic reducing power. Since new vessel growth is crucial for ovarian follicle development, a further aim of this study was to explore the expression of prepro-orexin and the effects of OXB on swine aortic endothelial cells. We found that the peptide is ineffective in modulating cell growth, while it inhibits redox status parameters. In addition, we demonstrated a stimulatory effect on angiogenesis evaluated in fibrin gel angiogenesis assay. Taken together, OXB appears to be potentially involved in the modulation of redox status in granulosa and endothelial cells and we could argue an involvement of the peptide in the follicular angiogenic events.

Keywords: ovarian follicle; oxidative stress; estradiol $17 \beta$; progesterone; angiogenesis

\section{Introduction}

Since their discovery in 1998 in the lateral hypothalamus [1,2], the neuropeptides orexin A and B and their receptors, OXR1 and OXR2, have been found to be widely distributed both in the nervous system and in many peripheral tissues. Several reports have recently highlighted the involvement of the orexin system in the regulation of many physiological processes, such as food intake and energy homeostasis [3], wakefulness and sleep [4], blood pressure [5] and emotional behaviors [6]. A modulatory effect of orexin B on adipose stromal cells' viability and adipogenic differentiation in the pig was recently shown, supporting the hypothesis that the orexinergic system could play a role in the physiology of adipose tissue, which is now recognized to possess different endocrine and metabolic functions [7-9]. Many indications exist concerning the potential role of orexins in the control of various endocrine axes, among which the hypothalamic-pituitarygonadal axis is included [10-13]. Within this perspective, although the role of the orexin 
system as an integrative link between energy homeostasis and reproduction has been hypothesized, its involvement in the regulation of the female reproductive system needs to be further clarified. The expression of prepro-orexin (PPO) gene and the presence of receptors have been confirmed in the ovary of different species [10,11,14-16]. In a recent work [17], we documented that porcine granulosa cells from large follicles express PPO mRNA as well as orexin receptors. Moreover, our findings about the effects of OXA on granulosa cell functional activity indicate that OXA and its receptors could modulate female reproductive functions through the control of ovarian steroidogenesis. In contrast, the role of OXB and OX2R in the regulation of reproductive activity has been poorly investigated. Kaminski et al. [18] and Kisielewska et al. [19] documented an involvement of OXB in the regulation of steroidogenesis by the porcine uterus during the luteal phase and early pregnancy. As for the gonads, Liguori et al. [20] provided the first evidence of OXB and OXR2 localization within the rat epididymis. In the female, a modulatory effect of OXB on ovarian steroidogenic activity was documented by Cataldi et al. [21] in the rat and Nitkiewicz et al. [12] in the pig. On these bases, this study was undertaken to localize $\mathrm{OXB}$ in sections of the whole porcine ovary as well as to examine the in vitro effect of different $\mathrm{OXB}$ concentrations on cell growth, steroidogenesis and redox status of granulosa cells $[16,17]$. Moreover, a further aim of the present research was to investigate the possible localization of OXB in follicular blood vessels, as we recently documented for OXA and its receptors [15]. These observations led us to hypothesize an involvement of the orexin system in the control of ovarian angiogenesis, a process tightly related to follicular growth and maturation. Thus, the present research was also aimed at studying this aspect in a swine aortic endothelial cell (AOC) model [22], firstly investigating the expression of the PPO gene. Moreover, the effect of OXB on AOC growth and redox status parameters was taken into account. In addition, the effect of OXB was explored using our previously set up fibrin gel angiogenesis bioassay [23].

\section{Materials and Methods}

All reagents used in this study were obtained from Sigma (St. Louis, MO, USA) unless otherwise specified.

\subsection{Collection of Ovaries}

For each experiment, we collected ovaries at a local slaughterhouse from 40 Large White cross-bred gilts (parity $=0$, aged 8-9 mo, weighing about $180 \mathrm{~kg}$ ), immediately after death. The evaluation of the estrous cycle was carried out on the basis of ovarian morphology as previously described $[24,25]$. Ovaries were placed into cold PBS $\left(4^{\circ} \mathrm{C}\right)$ supplemented with penicillin $(500 \mathrm{IU} / \mathrm{mL})$, streptomycin $(500 \mu \mathrm{g} / \mathrm{mL})$ and amphotericin B $(3.75 \mu \mathrm{g} / \mathrm{mL})$, maintained in a freezer bag and transported to the laboratory within $1 \mathrm{~h} \mathrm{[9]}$.

\subsection{Immunolocalization of $O X B$}

The ovaries collected from six gilts were treated with routine preparation of IHC on paraffin-embedded tissues for immunolocalization [17]. Briefly, tissues were fixed in $10 \%$ buffered formalin and embedded in paraffin. We obtained sections $5 \mu \mathrm{m}$ thick which were routinely stained (hematoxylin and eosin) and used for immunohistochemical studies by means of mouse monoclonal antibody anti-orexin B (MAB734, R\&D Systems, Inc., Minneapolis, MN, USA) [26]. Negative control sections were incubated with mouse $\mathrm{IgG}_{1}$ isotype control (MAB002, R\&D Systems, Inc., Minneapolis, MN, USA) using the same concentration of the primary antibody. Antigen retrieval was carried out by dipping the sections in $0.01 \mathrm{M}$ sodium citrate buffer, $\mathrm{pH}$ 6.0, and heating them in a microwave oven for $15 \mathrm{~min}$ at $400 \mathrm{~W}$. Thereafter, we incubated the sections in: (1) $3 \%$ hydrogen peroxidase for $15 \mathrm{~min}$ to block endogenous peroxidase; (2) primary antibody anti-orexin B at a dilution of 1:200 for $1 \mathrm{~h}$ at room temperature; (3) biotinylated goat anti-mouse IgG (BA-9200 Vector laboratories) at a dilution 1:200 for $30 \mathrm{~min}$; (4) Vectastain Elite ABC Peroxidase Kit (PK6100) for $30 \mathrm{~min}$; and (5) 3,3-diaminobenzidine (DAB substrate kit, peroxidase-Vector 
laboratories SK-4100) for $5 \mathrm{~min}$. After each step, washings of the sections were carried out with phosphate-buffered saline, pH 7.0 (PBS). The sections were counterstained with Mayer's hematoxylin solution. Histological slides were examined with a Nikon Eclipse E800 microscope (Nikon Corporation, Minato-Ku, Japan). Pictures of the sections were obtained with a DIGITAL SIGHT DS-Fi1 camera (Nikon Corporation, Minato-Ku, Japan)

\subsection{Evaluation of OXB Effect on Swine Granulosa Cell Function}

Morphological criteria were used to classify swine ovarian follicles as healthy. Atretic follicles and those with hemorrhagic, opaque or "milky" follicular fluid were excluded [27]. On the basis of our previous studies [17,22,28,29], as well as the classification of Foxcroft and Hunter [30], granulosa cells were aseptically harvested by aspiration of healthy follicles $>5 \mathrm{~mm}$ diameter with a 26-gauge needle and released in medium containing heparin $(50 \mathrm{IU} / \mathrm{mL})$. In order to also collect mural cells, granulosa cell collection was associated with a gentle scraping of the follicle wall with the needle. Cells were then centrifuged for pelleting and treated with $0.9 \%$ prewarmed ammonium chloride at $37^{\circ} \mathrm{C}$ for $1 \mathrm{~min}$ to remove red blood cells. In order to evaluate cell number and viability we used a hemocytometer under a phase contrast microscope after vital staining with trypan blue $(0.4 \%)$ of an aliquot of the cell suspension. After collection, cells were seeded in culture medium represented by DMEM/Ham's F12 supplemented with sodium bicarbonate (2.2 $\mathrm{mg} / \mathrm{mL}$ ), bovine serum albumin (BSA $0.1 \%)$, penicillin $(100 \mathrm{IU} / \mathrm{mL})$, streptomycin $(100$ $\mu \mathrm{g} / \mathrm{mL})$, amphotericin B $(2.5 \mu \mathrm{g} / \mathrm{mL})$, selenium $(5 \mathrm{ng} / \mathrm{mL})$ and transferrin $(5 \mu \mathrm{g} / \mathrm{mL})$, indicated hereafter as $\mathrm{CM}$. After seeding, cells were incubated for $48 \mathrm{~h}$ at $37^{\circ} \mathrm{C}$ under a humidified atmosphere $\left(5 \% \mathrm{CO}_{2}\right)$ with or without $\mathrm{OXB}$ at the concentration of $0.1,1$ and 10 $\mathrm{nM}$, previously examined in another study [12] and demonstrably close to the physiological range in swine blood [31].

\subsubsection{Granulosa Cell Viability and Proliferation}

We studied cell viability by means of MTT test (Sigma, St. Louis, MO, USA), which is a colorimetric assay based on tetrazolium salt 3-[4,5-dimethylthrazol-2-yl]-2,5dipheniltetrazolium bromide (MTT) reduction by mitochondrial dehydrogenase [32]. A total of $10^{4}$ cells were seeded in 96-well plates in $200 \mu \mathrm{L} \mathrm{CM}$ and treated with OXB for $48 \mathrm{~h}$, as indicated above. After each incubation, we added MTT $(5 \mathrm{mg} / \mathrm{mL})$ to cultured cells which were then incubated for $4 \mathrm{~h}$. In order to solubilize the reduction product, formazan, we added $100 \mu \mathrm{L}$ of lysis solution (SDS $10 \%$ in $\mathrm{HCl} 0.01 \mathrm{~N}$ ) to each well and left them at $37^{\circ} \mathrm{C}$ overnight. The absorbance was measured at $540 \mathrm{~nm}$ with Victor Reader (Perkin Elmer, Groningen, The Netherlands)

We determined cell proliferation with the ELISA BrdU (Roche Diagnostic, Indianapolis, IN, USA), an immunological colorimetric assay used for quantitative analysis, since BrdU can be incorporated into the newly synthesized DNA of replicating cells. Granulosa cells were plated into 96-well plates (Sarstedt, Nümbrecht, Germany) ( $10^{4}$ cells $/ 200 \mu \mathrm{L}$ of CM), and they were treated with the substance of interest and incubated overnight at $37^{\circ} \mathrm{C}$ in a humidified atmosphere [33]. Thereafter, they were incubated with $20 \mu \mathrm{L}$ of BrdU for $24 \mathrm{~h}$. After incubation, cells were fixed and DNA was denatured before adding the anti-BrdU antibody, conjugated with the enzyme peroxidase. During the $2 \mathrm{~h}$-incubation, we added $100 \mu \mathrm{L}$ of tetramethylbenzidine substrate (TMB), which develops a blue color after being oxidized by the enzyme in a quantity proportional to the amount of newly synthesized DNA. At the end, we stopped the reaction by adding $25 \mu \mathrm{L}$ of sulfuric acid (1M) which caused the sample to turn yellow. We measured absorbance values at $450 \mathrm{~nm}$ using a Victor Reader spectrophotometer. In order to determine viable cell number, the absorbance of each sample was read against a standard curve prepared by culturing, in quintuplicate, granulosa cells at different plating densities (from $10^{3}$ to $10^{5}$ viable $/ 200 \mu \mathrm{L}$ ) for $48 \mathrm{~h}$. The curve was repeated in four different experiments. The relationship between cell number and absorbance was linear $(r=0.92)$. Cell number/well was estimated from the resulting 
linear regression equation and was used to correct experimental data. The assay detection limit was $10^{3}$ cell/well and the variation coefficient was less than $5 \%$.

\subsubsection{Granulosa Cell Steroid Production}

A total of $10^{4}$ viable cells/well were seeded in 96-well plates in $200 \mu \mathrm{L} \mathrm{CM}$ supplemented with $28 \mathrm{ng} / \mathrm{mL}$ androstenedione [29] and treated with OXB for $48 \mathrm{~h}$ as above indicated. Thereafter, we collected culture media which were frozen and stored at $-20{ }^{\circ} \mathrm{C}$ until progesterone (P4) and estradiol $17 \beta$ (E2) determination by means of direct immunoenzymatic determination (Dia.Metra SRL, Spello, PG, Italy) [34]. The kits are based on competitive colorimetric immunoassay methods. As for the Estradiol ELISA kit, sample media were incubated at $37^{\circ} \mathrm{C}$ for $2 \mathrm{~h}$ and, after three washings, we added $100 \mu \mathrm{L}$ of TMB substrate; its reaction with $\mathrm{H}_{2} \mathrm{O}_{2}$ was catalyzed by the HPR enzyme present in the bound fraction. After a $30 \mathrm{~min}$ incubation in the dark the reaction product develops a blue color that turns to yellow after the addition of the stop solution. The concentration of the hormone is determined on the basis of a 5-point calibration curve from 0 to $2000 \mathrm{pg} / \mathrm{mL}$. The data are processed by the spectrophotometer; the absorbance is read at $450 \mathrm{~nm}$ against a reference wavelength of $620-630 \mathrm{~nm}$. The within-assay variability was $<9 \%$. The direct immunoenzymatic determination of progesterone was performed on the same bases; the concentration of progesterone in the sample was calculated against a 4-point calibration curve from 0 to $40.0 \mathrm{ng} / \mathrm{mL}$. The ELISA progesterone kit requires a $1 \mathrm{~h}$ incubation at $37{ }^{\circ} \mathrm{C}$; after the removal of the unbound antibody, we added $100 \mu \mathrm{L}$ of substrate TMB and we left the plate to incubate for $15 \mathrm{~min}$ at $37^{\circ} \mathrm{C}$ away from light. After the stopping of reaction, the absorbance was read at $450 \mathrm{~nm}$ against a reference wavelength of 620-630 $\mathrm{nm}$ using the Victor Reader. The within-assay variability was $<4 \%$.

\subsubsection{Granulosa Cell Redox Status}

Granulosa Cell Superoxide $\left(\mathrm{O}_{2}{ }^{-}\right)$Production

$\mathrm{O}_{2}{ }^{-}$production was evaluated by WST-1-(4-[3-(4-iodophenyl)-2-(4-nitrophenyl)-2H5-tetrazolium]-1,3-benzene disulfonate) test (Roche, Mannheim, Germany). The assay is based on the cleavage of the water-soluble tetrazolium salt WST-1 to a yellow-orange, water-soluble formazan. Experimental data document that tetrazolium salts can be used as a reliable measure of intracellular $\mathrm{O}_{2}{ }^{-}$production [22]. A total of $10^{4}$ viable cells $/ 200 \mu \mathrm{L}$ CM were seeded in 96-well plates, treated with OXB as above described and incubated for $48 \mathrm{~h}$. During the last $4 \mathrm{~h}$ of treatment, we added $20 \mu \mathrm{L}$ WST-1 to cells and absorbance was then determined using the Victor Reader at a wavelength of 450 against $620 \mathrm{~nm}$.

\section{Granulosa Cell Nitric Oxide (NO) Production}

A total of $10^{5}$ viable cells $/ 200 \mu \mathrm{L} \mathrm{CM}$ were seeded in 96-well plates and treated with OXB for $48 \mathrm{~h}$ as previously described. NO was quantified by measuring nitrite levels in culture media by the microplate method based on the formation of chromophores after reaction with Griess reagent, which was prepared fresh daily by mixing equal volumes of stock A ( $1 \%$ sulfanilamide, $5 \%$ phosphoric acid $)$ and stock B $(0.1 \% N$-[naphthyl] ethylenediamine dihydrochloride) [35].

\section{Granulosa Cell Non-Enzymatic Scavenging Activity}

The ferric reducing ability of plasma (FRAP) assay is a colorimetric method based on the ability of the antioxidant molecules to reduce ferric-tripiridyltriazine $\left(\mathrm{Fe}^{3+} \mathrm{TPTZ}\right)$ to a ferrous form $\left(\mathrm{Fe}^{2+} \mathrm{TPTZ}\right) . \mathrm{Fe}^{2+}$ is measured spectrophotometrically via determination of its colored complex with 2,4,6-Tris(2-pyridyl)-s-triazine (Fe $\left.{ }^{2+} \mathrm{TPTZ}\right)$. TPTZ reagent was prepared before use, mixing $25 \mathrm{~mL}$ of acetate buffer, $2.5 \mathrm{~mL}$ of 2,4,6-Tris(2-pyridyl)-striazine (TPTZ) $10 \mathrm{mM}$ in $\mathrm{HCl} 40 \mathrm{mM}$ and $\mathrm{FeCl}^{3-} 6 \mathrm{H}_{2} \mathrm{O}$ solution. Briefly, $2 \times 10^{5}$ viable cells $/ 200 \mu \mathrm{L}$ CM were seeded in 96-well plates and treated with OXB for $48 \mathrm{~h}$ as previously described. At the end, plates were centrifuged for $10 \mathrm{~min}$ at $400 \times g$, supernatants were discarded and cells were lysed by adding cold Triton $0.5 \%+$ PMSF in PBS (200 $\mu \mathrm{L} /$ well), 
incubating on ice for $30 \mathrm{~min}$. The test was carried out on $40 \mu \mathrm{L}$ of cell lysates added to $\mathrm{Fe}^{3+} \mathrm{TPTZ}$ reagent and then incubated at $37^{\circ} \mathrm{C}$ for $30 \mathrm{~min}$. The absorbance of $\mathrm{Fe}^{2+} \mathrm{TPTZ}$ was determined by Victor Reader at $595 \mathrm{~nm}$. We determined the ferric reducing ability of cell lysates by plotting a standard curve of absorbance against $\mathrm{FeSO}_{4}{ }^{-} 7 \mathrm{H}_{2} \mathrm{O}$ standard solution [36].

\subsection{Evaluation of OXB Effects on Swine Aortic Endothelial Cell (AOC) Function}

\subsubsection{AOC Culture}

The immortalized porcine aortic endothelial cell line (AOC) used in the experiments was kindly provided by Prof. Jose Yélamos (Hospital Universitario Virgen de la Arrixaca, El Palmar, Murcia, Spain) [27]. We used cells at the 13th passage which were grown in Medium 199 (containing Earle's salts and l-glutamine) supplemented with sodium bicarbonate $(2.2 \mathrm{mg} / \mathrm{mL})$, penicillin $(100 \mathrm{IU} / \mathrm{mL})$, streptomycin $(100 \mu \mathrm{g} / \mathrm{mL})$, amphotericin B $(2.5 \mathrm{mg} / \mathrm{mL})$ and $20 \%$ FBS (fetal bovine serum) (GIBCO ${ }^{\mathrm{TM}}$, Invitrogen Corporation, Renfrew, UK), indicated as $\mathrm{CM} 2$, and incubated at $37^{\circ} \mathrm{C}$ in a humidified atmosphere (5\% $\left.\mathrm{CO}_{2}\right)$.

\subsubsection{AOC Prepro-Orexin Expression Evaluation}

Total RNA was extracted from $10^{6}$ AOCs using Nucleospin®RNA II (Macherey-Nagel Gmbh, Duren, Germany) according to the manufacturer's instructions. Total RNA was quantified by absorbance at $260 \mathrm{~nm}$ (Gen Quant Pro, Amersham Bioscences, Freiburg, Germany). Total RNA $(2 \mu \mathrm{g})$ was reverse transcribed with RevertAid First Strand cDNA Synthesis (Thermo Fisher Scientific, Waltham, MA, USA). Semiquantitative analysis of preproorexin (PPO) gene expression (accession number EF434655) was performed by nested PCR. We carried out two sequential runs of PCR with two different sets of primers complementary to swine PPO cDNA (nested PCR). The primers used for the second run were designed to amplify a sequence target within the first run product. For the first amplification run, the following primer pair was used: forward 5'-AAGACGACACCCTTCCTGGAGAC-3'; reverse 5'-TGATTGCCAGCGCCGTGTAGCA-3' (amplicon length: $221 \mathrm{bp}$ ). After a first 1 min denaturation step at $94{ }^{\circ} \mathrm{C}$, the following PCR cycle was repeated 35 times: $94{ }^{\circ} \mathrm{C}$ for $30 \mathrm{~s}$, then $58^{\circ} \mathrm{C}$ for $30 \mathrm{~s}$ and $72{ }^{\circ} \mathrm{C}$ for $30 \mathrm{~s}$. A final elongation step was performed at $72{ }^{\circ} \mathrm{C}$ for $10 \mathrm{~min}$. For the second PCR run, the following nested primers were used: forward $5^{\prime}$ TCCTTTTCGAAAGGTCTCCTGG-3 ${ }^{\prime}$, and reverse $5^{\prime}$-GTGTAGCAGCTCGTAGAGGCG- ${ }^{\prime}$ (amplicon length: $154 \mathrm{bp}$ ). The amplification was performed at the same conditions as described above except for cycle number (34). Actin (ACT) was chosen as housekeeping gene co-amplified with the interest genes $[17,32,37]$.

\subsubsection{AOC Viability and Proliferation}

In order to evaluate cell viability and cell proliferation, we seeded AOC in 96-well plates at a density of $1.5 \times 10^{3}$ cells/well in $200 \mu \mathrm{L} \mathrm{CM} 2$ and incubated them at $37^{\circ} \mathrm{C}$ in a humidified atmosphere $\left(5 \% \mathrm{CO}_{2}\right)$. After $24 \mathrm{~h}$, medium was changed and additional incubation was performed with or without OXB $10 \mathrm{nM}$ for $48 \mathrm{~h}$. Cell viability was evaluated by MTT assay and cell proliferation was measured with BrdU test as above described for granulosa cells.

\subsubsection{AOC Redox Status}

A total of $1.5 \times 10^{3}$ viable cells $/ 200 \mu \mathrm{L}$ CM2 were seeded in 96-well plates and incubated at $37^{\circ} \mathrm{C}$ in a humidified atmosphere $\left(5 \% \mathrm{CO}_{2}\right)$. After $24 \mathrm{~h}$, medium was renewed and cells were treated for $48 \mathrm{~h}$ with OXB $10 \mathrm{nM}$. WST-1 was added to cells during the last $4 \mathrm{~h}$ to quantify $\mathrm{O}_{2}{ }^{-}$output as previously described for granulosa cells.

A total of $5 \times 10^{4}$ viable cells $/ 200 \mu \mathrm{L} \mathrm{CM} 2$ were seeded in 96 -well plates and incubated at $37{ }^{\circ} \mathrm{C}$ in a humidified atmosphere $\left(5 \% \mathrm{CO}_{2}\right.$ and $\left.19 \% \mathrm{O}_{2}\right)$. After $24 \mathrm{~h}$, medium was renewed and cells were treated for $48 \mathrm{~h}$ with OXB $10 \mathrm{nM}$. At the end of the incubation 
period, the media were collected, and NO content was assayed with Griess reagents, as described above for granulosa cells.

A total of $5 \times 10^{4}$ viable cells $/ 200 \mu \mathrm{L} \mathrm{CM} 2$ were seeded in 24-well plates and incubated at $37^{\circ} \mathrm{C}$ in a humidified atmosphere $\left(5 \% \mathrm{CO}_{2}\right.$ and $\left.19 \% \mathrm{O}_{2}\right)$ for $24 \mathrm{~h}$. The medium was then renewed, and the cells were incubated for $48 \mathrm{~h}$ with OXB $10 \mathrm{nM}$. Then, cells were lysed and non-enzymatic scavenger activity was assayed with the FRAP method, as previously described for granulosa cells.

\subsubsection{Angiogenesis Bioassay}

The microcarrier-based fibrin gel angiogenesis assay was carried out as described [38] with some modifications. Briefly, $12.5 \mathrm{mg}$ gelatin-coated cytodex-3 microcarriers in $1 \mathrm{~mL}$ PBS were incubated for $3 \mathrm{~h}$ to hydrate. After two washings in PBS and one in CM2, the microcarriers were put in flasks containing $5 \mathrm{~mL} \mathrm{CM} 2$; AOC $\left(5 \times 10^{5}\right)$ were added and cultured for $24 \mathrm{~h}$ in order to let the endothelial cells coat the microcarriers. For the fibrin gel preparation, $40 \mu \mathrm{L}$ microcarriers covered by AOC were pipetted into 6-well plates containing a solution of fibrinogen $(1 \mathrm{mg} / \mathrm{mL}$ PBS, pH 7.6), with $1250 \mathrm{IU}$ thrombin $(250 \mu \mathrm{L})$. Fibrin gels were allowed to polymerize for $30 \mathrm{~min}$ at $37^{\circ} \mathrm{C}$, and then were equilibrated for 60 min with $2 \mathrm{~mL}$ M199. After medium renewal, we incubated AOC with or without OXB $10 \mathrm{nM}$. Plates were incubated at $37^{\circ} \mathrm{C}$ under a humidified atmosphere $\left(5 \% \mathrm{CO}_{2}\right)$. AOC were cultured for $72 \mathrm{~h}$, and the treatment was completely renewed after $48 \mathrm{~h}$ as described above. Endothelial cell proliferation in the fibrin gel matrix was evaluated by means of the public domain NIH Program Scion Image Beta 4.02. Ten pictures were taken for each gel at 48 and $72 \mathrm{~h}$; images were converted into gray scale, resized to 50\% (Paintbrush Software, MS Office) and saved in a Bitmap 24 bit format compatible with Scion. The modified images were then imported into the program and measurements were carried out by drawing the perimeter of the area occupied by AOC expressed as number of pixels. In order to validate the measurement of the area covered by AOC in fibrin gels as a reliable method to evaluate cell proliferation, we stained fibrin gels with the nuclear dye bisbenzimide (Hoechst 33258, $20 \mu \mathrm{g} / \mathrm{mL}$ in PBS for $60 \mathrm{~min}$ ) and then we examined them by fluorescence microscope. This procedure was performed 20 times; for each experiment the number of nuclei was counted under fluorescence and pictures of the area covered by AOC were taken in order to measure the surface covered in the fibrin gel. A strong correlation was observed between the area covered by AOC and the number of nuclei found in the same area $(r=0.96)$.

\subsection{Statistical Analysis}

The experiments were repeated at least 5 times (6 replicates/treatment). Every time the ovaries were collected from 40 gilts. Experimental data are presented as mean \pm SEM; statistical differences among treatments were calculated with ANOVA using Statgraphics package (STSC Inc., Rockville, MD, USA). When significant differences were found, means were compared by Scheffè's F test; $p$ values $<0.05$ were considered to be statistically significant.

\section{Results}

3.1. Immunolocalization of $O X B$ and Its Effects on Swine Granulosa Cell Function

Immunohistochemical cytoplasmatic positivity was observed for OXB both in granulosa and in thecal cells of swine ovarian follicles (Figure 1). 

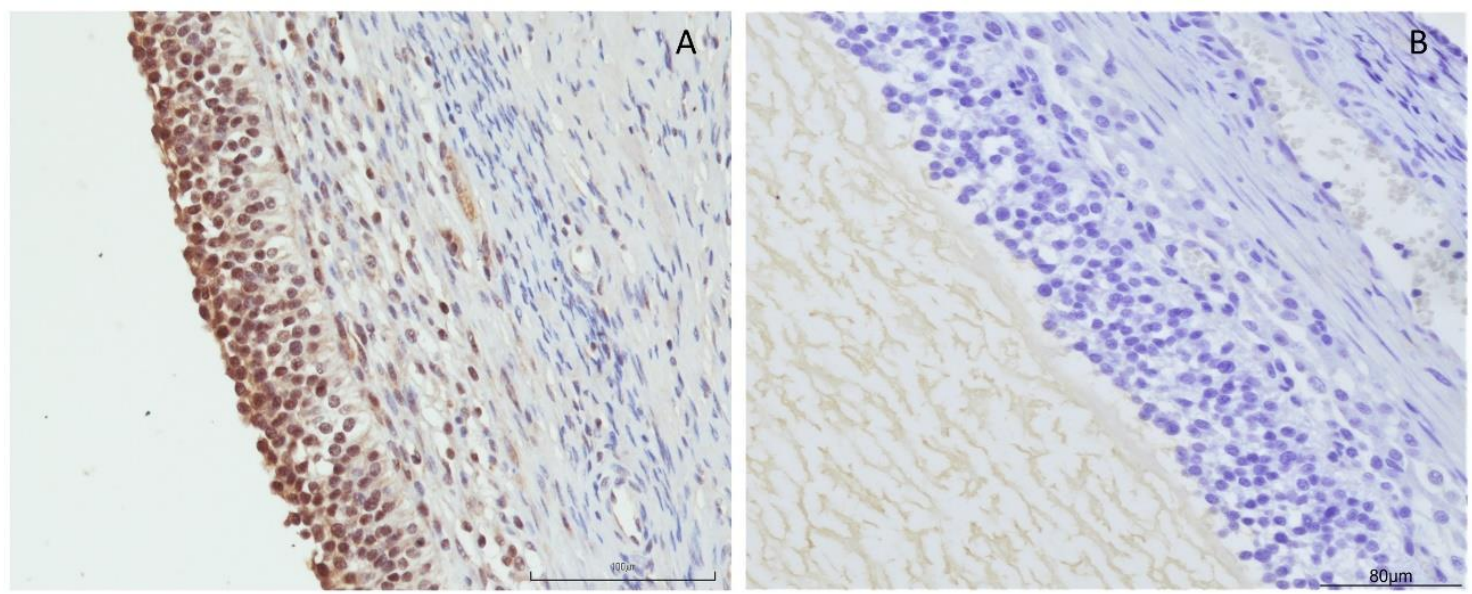

Figure 1. (A) Cytoplasmatic positivity for orexin B in granulosa cells (20X IHC). Scale bar $=100 \mu \mathrm{m}$. (B) Negative control.

OXB did not affect either granulosa cell viability or granulosa cell proliferation at the concentrations tested (Figure 2).
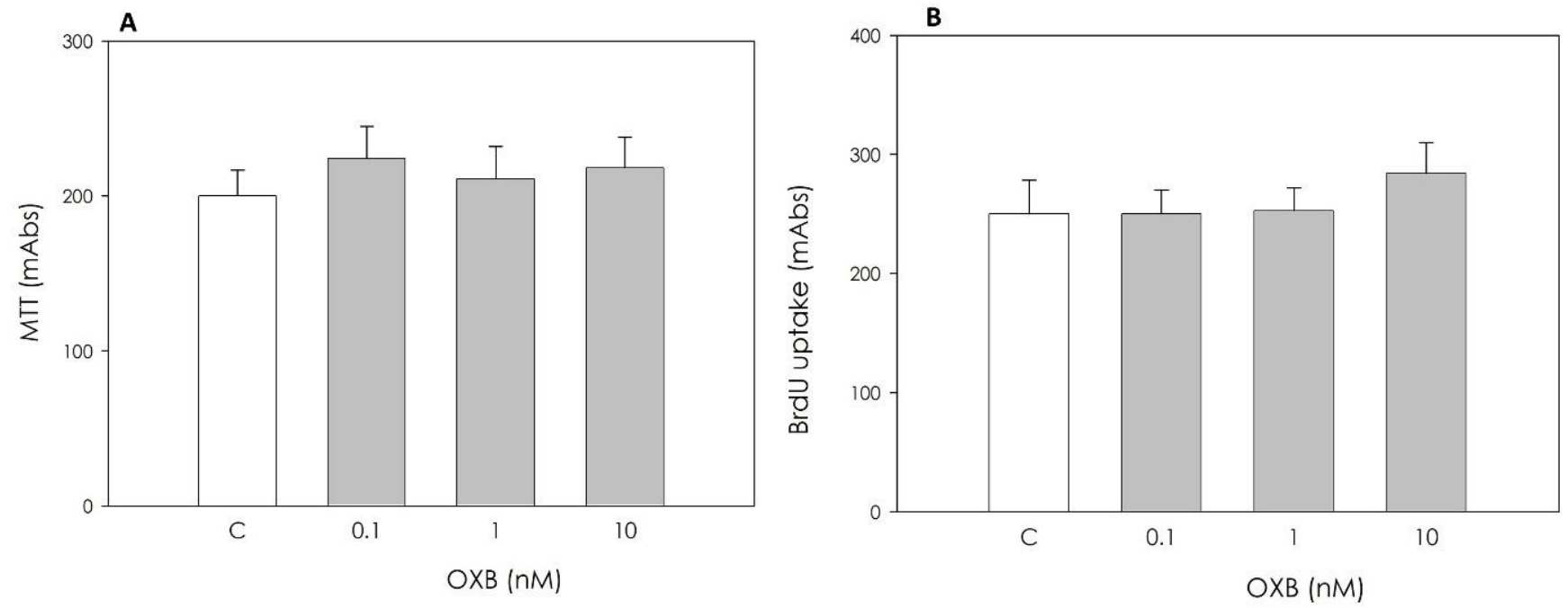

Figure 2. Effect of the $48 \mathrm{~h}$ treatment with orexin B (OXB; $0.1,1$ and $10 \mathrm{nM}$ ) on swine granulosa cell viability, evaluated by MTT test (A), and on granulosa cell proliferation evaluated using 5-bromo-2'-deoxyuridine (BrdU) incorporation assay test (B). Data, expressed as milliAbsorbance (mAbs), represent the mean \pm SEM of six replicates/treatment repeated in five different experiments.

Steroidogenic activity, evaluated by ELISA assays, was not influenced by the peptide (Figure 3).

With regard to the granulosa cells' redox status, OXB did not affect $\mathrm{O}_{2}{ }^{-}$production (Figure 4A). On the contrary, NO production was significantly stimulated $(p<0.05)$ by $10 \mathrm{nM}$ OXB (Figure $4 \mathrm{~B}$ ), and granulosa cell non-enzymatic scavenging activity was increased by treatment with all concentrations tested $(p<0.01)$ (Figure $4 \mathrm{C}$ ). 

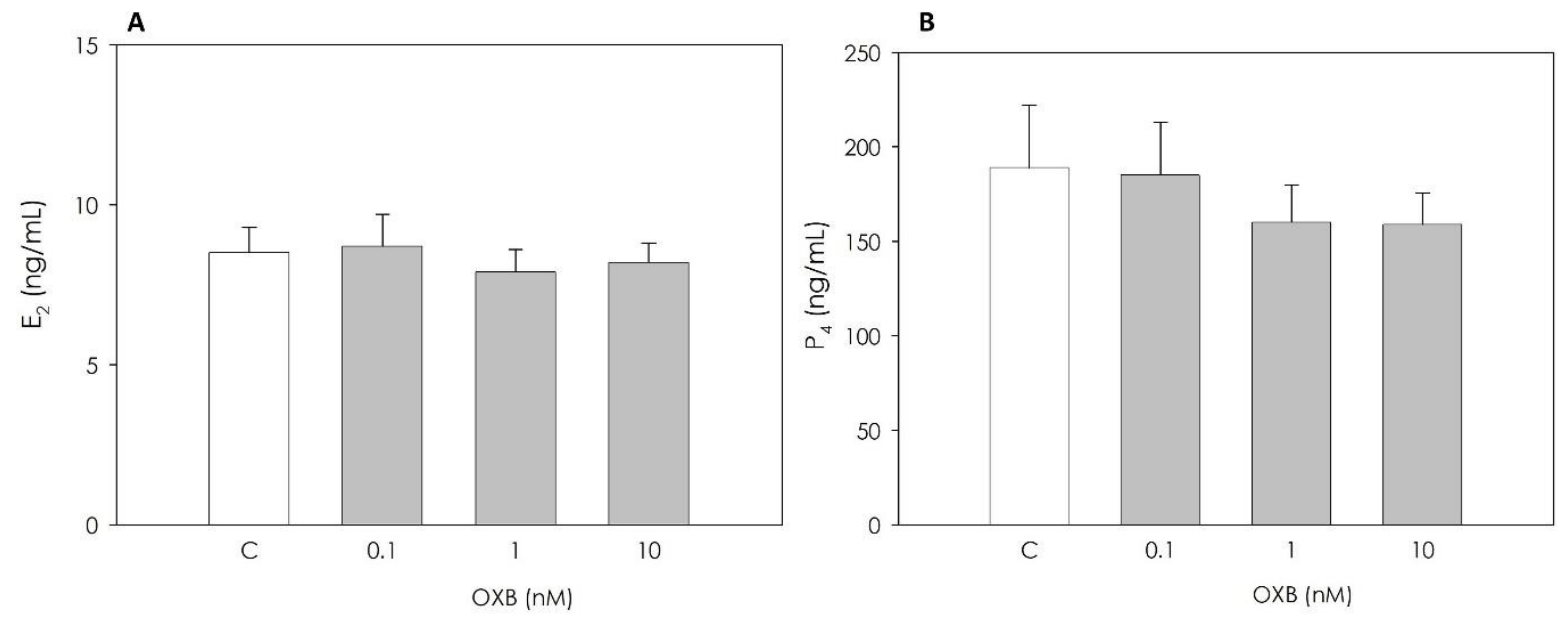

Figure 3. Effect of the $48 \mathrm{~h}$ treatment with orexin B (OXB; 0.1, 1 and $10 \mathrm{nM}$ ) on swine granulosa cell estradiol 17 $\beta$ (E2) and progesterone (P4) production (panels (A) and (B), respectively) evaluated by ELISA tests. Data, expressed as ng/mL, represent the mean \pm SEM of six replicates/treatment repeated in five different experiments.
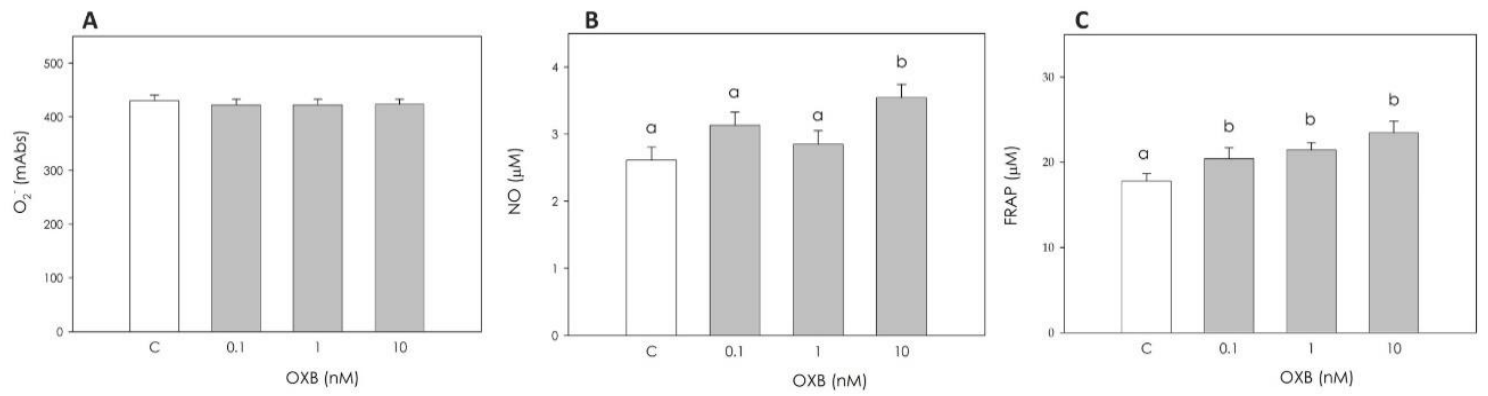

Figure 4. Effect of the $48 \mathrm{~h}$ treatment with orexin $\mathrm{B}(\mathrm{OXB} ; 0.1,1$ and $10 \mathrm{nM})$ on swine granulosa cell superoxide anion generation $\left(\mathrm{O}_{2}{ }^{-}\right)$using WST assay $(\mathbf{A})$, nitric oxide (NO) production using Griess assay $(\mathbf{B})$ and non-enzymatic scavenging activity using FRAP assay (C). Data, expressed as milliAbsorbance (mAbs), represent the mean $\pm \mathrm{SEM}$ of six replicates/treatment repeated in five different experiments. In each panel, different letters on the bars indicate a significant difference $(p<0.05)$ among treatments as calculated by ANOVA and Scheffè's F test.

\subsection{PPO Expression and OXB Effects on Swine Aortic Endothelial Cells}

Figure 5 shows PPO expression in AOC.

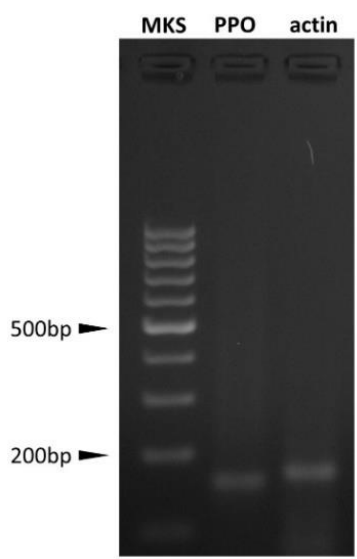

Figure 5. Prepro-orexin (PPO) and actin (ACT) expression in swine aortic endothelial cells (AOC). PPO expression was evaluated by nested PCR; the presence of PPO amplicon demonstrates gene expression but does not provide any information in comparison to ACT expression. 
Neither cell viability nor cell proliferation were influenced by OXB (Figure 6).
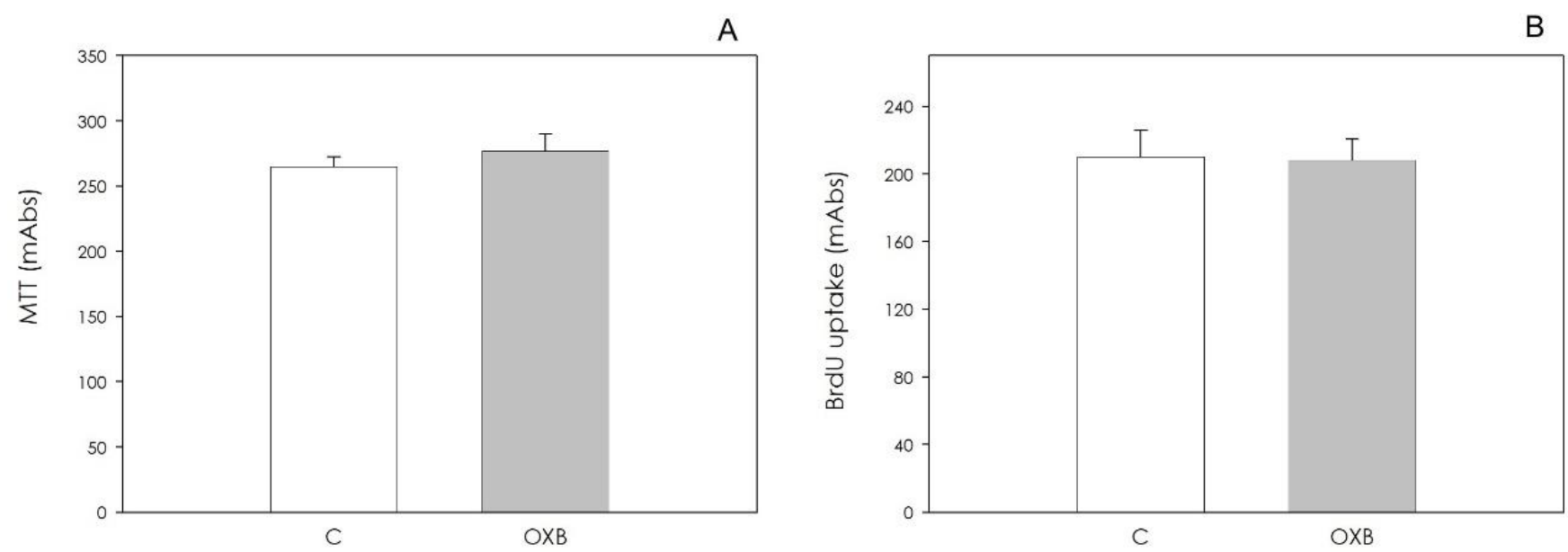

Figure 6. Effect of the $48 \mathrm{~h}$ treatment with orexin B (OXB; $10 \mathrm{nM})$ on swine aortic endothelial cells' viability, evaluated by MTT test (A) and on granulosa cell proliferation evaluated using 5-bromo-2'-deoxyuridine (BrdU) incorporation assay test (B).

On the contrary, redox status was affected by the peptide, which significantly inhibited $(p<0.05)$ both $\mathrm{O}_{2}$ and $\mathrm{NO}$ generation (Figure 7A,B). Non-enzymatic scavenging activity was also significantly $(p<0.05)$ reduced (Figure $7 \mathrm{C})$.

A

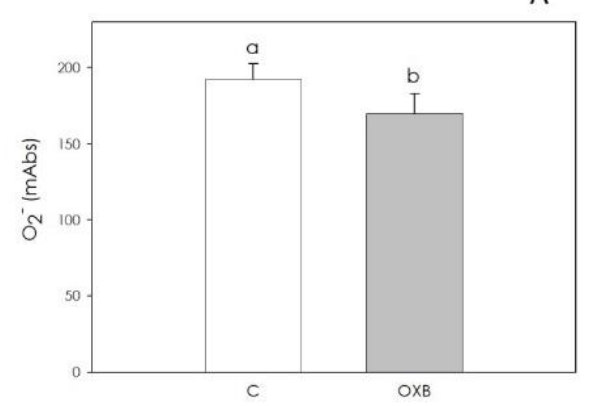

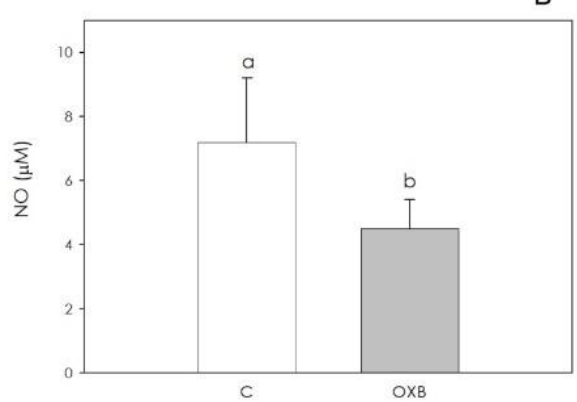

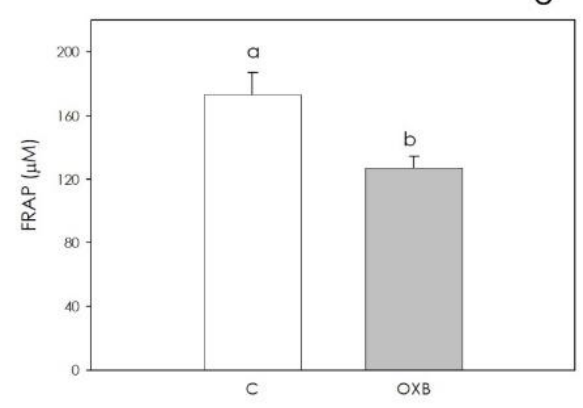

Figure 7. Effect of the $48 \mathrm{~h}$ treatment with orexin $\mathrm{B}(\mathrm{OXB} ; 10 \mathrm{nM})$ on swine aortic endothelial cells' superoxide anion generation $\left(\mathrm{O}_{2}{ }^{-}\right)$using WST assay $(\mathbf{A})$, nitric oxide (NO) production using Griess assay $(\mathbf{B})$ and non-enzymatic scavenging activity using FRAP assay (C). Data, expressed as milliAbsorbance (mAbs), represent the mean \pm SEM of six replicates/treatment repeated in five different experiments. In each panel, different letters on the bars indicate a significant difference $(p<0.05)$ among treatments as calculated by ANOVA and Scheffè's F test.

Fibrin gel angiogenesis bioassay revealed that OXB, while ineffective after a $48 \mathrm{~h}$ treatment (Figure 8), exerted a significant $(p<0.001)$ stimulatory effect after $72 \mathrm{~h}$ (Figure 9). 
A

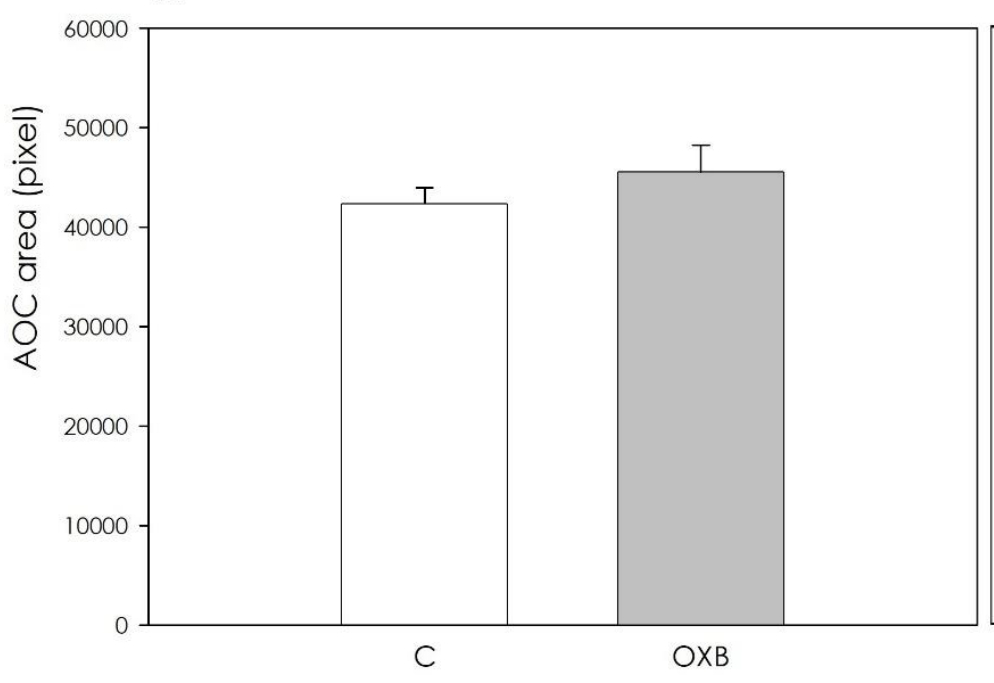

B

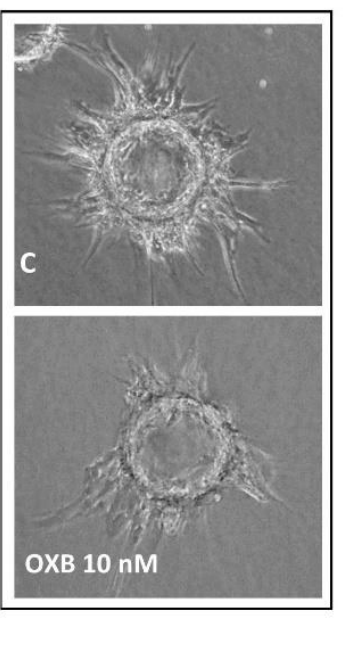

Figure 8. Effect of the $48 \mathrm{~h}$ treatment with OXB (10 nM) on aortic endothelial cell (AOC) growth in fibrin gels. Panel (A): data, expressed as pixels, represent the mean $\pm \mathrm{SEM}$ of six replicates/treatment repeated in five different experiments. Panel (B): exemplary images of the AOC growing on collagencoated MC beads in fibrin gels, both after $48 \mathrm{~h}$ of treatment with OXB (10 nM).
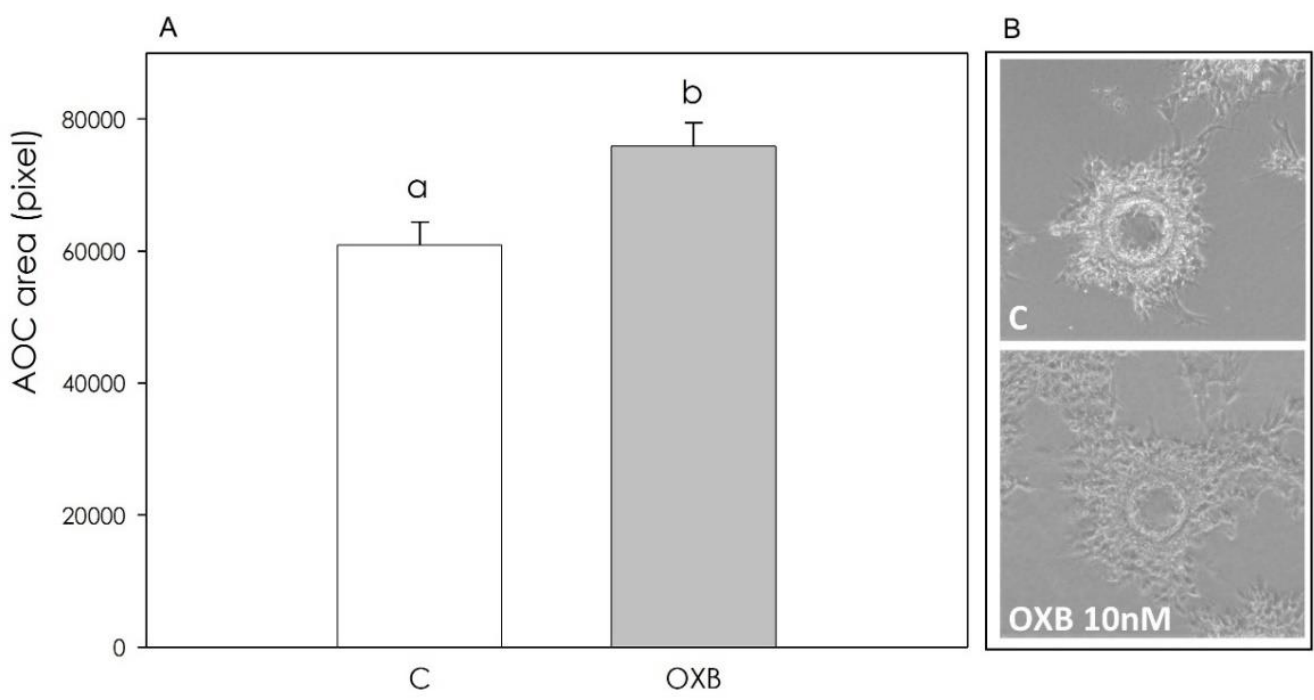

Figure 9. Effect of the $72 \mathrm{~h}$ treatment with OXB $(10 \mathrm{nM})$ on aortic endothelial cell (AOC) growth in fibrin gels. Panel (A): data, expressed as pixels, represent the mean $\pm \mathrm{SEM}$ of six replicates/treatment repeated in five different experiments. Different letters on the bars indicate a significant difference $(p<0.001)$ among treatments as calculated by ANOVA and Scheffè's F test. Panel (B): exemplary images of the AOC growing on collagen-coated MC beads in fibrin gels both after $72 \mathrm{~h}$ of treatment with OXB (10 nM).

\section{Discussion}

The involvement of OXA and OXB in the modulation of reproductive activity is supported by different studies documenting their regulatory role on the HPG axis [13] by means of a modulation of GnRH and LH secretion in different species [21,39-41]. In addition, orexins appear also to be involved in the local control of gonadal physiology. Our research group has previously demonstrated the presence and expression of the orexinergic complex in the pig ovary [15-17]. In particular, we have shown that OXA and its receptors are expressed both in the corpus luteum as well as in granulosa cells. The physiological 
role played by OXA in the ovary is further supported by our results documenting its effects on both luteal and granulosa cell functions [15-17].

The present data document the fact that OXB is immunolocalized in both swine granulosa and thecal cells and is a likely candidate to play a role in the local regulation of reproductive activity. Our data show that the examined peptide does not affect granulosa cell growth and steroidogenesis. A previous report [12] is only partially in accordance with our finding, since it demonstrates an inhibitory effect induced by OXB on estradiol output. However, it should be noted that the cell model used in the study is relative to granulosa cells which underwent luteinization due to the presence of serum in culture medium. The effect of OXB was also tested in the presence of FSH, while we explored the effect of OXB in the absence of the gonadotropin, to study its potential influence in basal conditions as in our previous studies [7,17]. Further studies should be planned to investigate the steroidogenic effect of OXB in the presence of FSH stimulation. Moreover, it should be noted that the orexin peptides bind selectively to the OX1 and OX2 receptors (OX1R and OX2R, also known as HCRTR1 and HCRTR2). These are G-protein-coupled receptors that have seven transmembrane domains and some similarity to other neuropeptide receptors. OX1R and OX2R are strongly conserved across mammals, with $94 \%$ identity in the amino acid sequences between humans and rats. OX1R binds OXA with high affinity (IC50 $20 \mathrm{nM}$ in a competitive binding assay), but it has considerably less affinity for OXB (IC50 $420 \mathrm{nM}$ ) [42]. These aspects could be involved and the effects of receptor antagonists need to be investigated in further experiments. However, even though most granulosa cell functions were not modified by OXB treatment, including the generation of superoxide anion, significant effects on redox status were observed, namely an increase in both nitric oxide and non-enzymatic scavenger activities. As a general remark, the effect of OXB has been less investigated, possibly due to its considerably lesser affinity for OX2. However, Sokołowska et al. [43] demonstrated a potent antioxidant effect of OXB in primary neuronal rat culture and a therapeutic use has also been hypothesized [44]. It should be noted that our findings are of particular interest, since redox status regulation generally plays a central role in follicular function. In particular, a crucial modulatory action on ovarian physiology has been demonstrated for a multifaced molecule such as nitric oxide [45].

Potential effects of OXB on endothelial cell redox status and nitric oxide secretion were also studied in swine aortic cells; our data document the fact that OXB can also affect endothelial cell free radical balance, since both superoxide anion and nitric oxide production appeared reduced, as well as non-enzymatic scavenging activity. A protective effect against oxidative stress has already been demonstrated for OXA [46]. To our knowledge, these aspects have never been investigated before, but deserve to be further explored, since redox status is crucial for a physiological endothelial function [47]. Our data point out a local expression of $\mathrm{OXB}$, thus suggesting its potential involvement in the regulation of cellular function. PPO expression has been previously assessed in rat aortic cells by Johren et al. [48] and several studies [49,50] indicate effects of orexins in cardiovascular functions. It has been previously shown [51] that OXA induces angiogenesis via the orexin receptors, indicating that the peptide and its receptors play important roles in new vessel growth under pathophysiological conditions. To our knowledge, the effect of OXB has never been investigated before. Our data indicate that, while OXB appeared ineffective in modulating endothelial cells' growth, it displayed a stimulatory effect on angiogenesis, as evaluated by means of our in vitro three-dimensional fibrin gel bioassay. This result would suggest a fundamental role offered by the fibrin mesh, a three-dimensional (3D) support on which endothelial cells organize into capillary-like structures on the surface of the substrate and invade the surrounding matrix, developing tubular structures inside the matrix. The three-dimensional model reflects more closely the in vivo situation. The three-dimensional assay supports capillary invasion into the matrix, outgrowth of tubular structures, sprouting from cells attached on microcarrier beads, and formation of capillary networks. Overall, these aspects need to be better clarified since angiogenesis plays a pivotal role in follicular growth and development [52]. 


\section{Conclusions}

The present study expands our previous findings on the orexin system in swine ovarian follicles, demonstrating a potential functional role of OXB in the control of redox status in granulosa and endothelial cells and suggesting an involvement of the peptide in the follicular angiogenic events.

Author Contributions: Conceptualization, supervision, writing—original draft preparation, writingreview and editing, G.B.; data curation, S.B., S.G., C.D. and R.D.L.; writing-review and editing, F.G. All authors have read and agreed to the published version of the manuscript.

Funding: This research was supported by the Program "FIL" of the University of Parma.

Institutional Review Board Statement: The study was conducted using discarded samples collected at a slaughterhouse.

Informed Consent Statement: Not applicable.

Data Availability Statement: Data are available upon request.

Conflicts of Interest: The authors declare no conflict of interest.

\section{References}

1. de Lecea, L.; Kilduff, T.S.; Peyron, C.; Gao, X.; Foye, P.E.; Danielson, P.E.; Fukuhara, C.; Battenberg, E.L.; Gautvik, V.T.; Bartlett, F.S., 2nd; et al. The hypocretins: Hypothalamus-specific peptides with neuroexcitatory activity. Proc. Natl. Acad. Sci. USA 1998, 95, 322-327. [CrossRef]

2. Sakurai, T.; Amemiya, A.; Ishii, M.; Matsuzaki, I.; Chemelli, R.M.; Tanaka, H.; Williams, S.C.; Richardson, J.A.; Kozlowski, G.P.; Wilson, S.; et al. Orexins and orexin receptors: A family of hypothalamic neuropeptides and G protein-coupled receptors that regulate feeding behavior. Cell 1998, 92, 573-585. [CrossRef]

3. Liu, L.; Wang, Q.; Liu, A.; Lan, X.; Huang, Y.; Zhao, Z.; Jie, H.; Chen, J.; Zhao, Y. Physiological Implications of Orexins/Hypocretins on Energy Metabolism and Adipose Tissue Development. ACS Omega 2019, 5, 547-555. [CrossRef] [PubMed]

4. Sakurai, T. The neuralcircuit of orexin (hypocretin): Maintaining sleep and wakefulness. Nat. Rev. Neurosci. 2007, 8, 171-181. [CrossRef]

5. Chieffi, S.; Carotenuto, M.; Monda, V.; Valenzano, A.; Villano, I.; Precenzano, F.; Tafuri, D.; Salerno, M.; Filippi, N.; Nuccio, F.; et al Orexin System: The Key for a Healthy Life. Front. Physiol. 2017, 8, 357. [CrossRef] [PubMed]

6. Pan, Y.P.; Liu, C.; Liu, M.F.; Wang, Y.; Bian, K.; Xue, Y.; Chen, L. Involvement of orexin-A in the regulation of neuronal activity and emotional behaviors in central amygdala in rats. Neuropeptides 2020,80, 102019. [CrossRef]

7. Basini, G.; Bussolati, S.; Grolli, S.; Ragionieri, L.; Di Lecce, R.; Grasselli, F. Orexin B inhibits viability and differentiation of stromal cells from swine adipose tissue. Domest. Anim. Endocrinol. 2021, 75, 106594. [CrossRef]

8. Gigante, P.; Berni, M.; Bussolati, S.; Grasselli, F.; Grolli, S.; Ramoni, R.; Basini, G. Glyphosate affects swine ovarian and adipose stromal cell functions. Anim. Reprod. Sci. 2018, 195, 185-196. [CrossRef] [PubMed]

9. Berni, M.; Gigante, P.; Bussolati, S.; Grasselli, F.; Grolli, S.; Ramoni, R.; Basini, G. Bisphenol S, a Bisphenol A alternative, impairs swine ovarian and adipose cell functions. Domest. Anim. Endocrinol. 2019, 66, 48-56. [CrossRef] [PubMed]

10. Silveyra, P.; Cataldi, N.I.; Lux-Lantos, V.A.; Libertun, C. Role of orexins in the hypothalamic-pituitary-ovarian relationships. Acta Physiol. 2010, 198, 355-360. [CrossRef]

11. Nitkiewicz, A.; Smolinska, N.; Przala, J.; Kaminski, T. Expression of orexin receptors 1 (OX1R) and 2 (OX2R) in the porcine ovary during the oestrous cycle. Regul. Pept. 2010, 165, 186-190. [CrossRef] [PubMed]

12. Nitkiewicz, A.; Smolinska, N.; Maleszka, A.; Chojnowska, K.; Kaminski, T. Expression of orexins and their precursor in the porcine ovary and the influence of orexins on ovarian steroidogenesis in pigs. Anim. Reprod. Sci. 2014, 148, 53-62. [CrossRef] [PubMed]

13. Kaminski, T.; Smolinska, N.; Nitkiewicz, A.; Przala, J. Expression of orexin receptors 1 (OX1R) and 2 (OX2R) in the porcine hypothalamus during the oestrous cycle. J. Physiol. Pharmacol. 2010, 61, 363-371.

14. Levanti, M.; Germanà, A.; Abbate, F. Orexin A expression in the ovary of dog and cat. Reprod. Domest. Anim. 2015, 50, 247-250. [CrossRef]

15. Ragionieri, L.; Ravanetti, F.; Di Lecce, R.; Botti, M.; Ciccimarra, R.; Bussolati, S.; Basini, G.; Gazza, F.; Cacchioli, A. Immunolocalization of Orexin A and its receptors in the different structures of the porcine ovary. Ann. Anat. 2018, 218, 214-226. [CrossRef]

16. Basini, G.; Ciccimarra, R.; Bussolati, S.; Grolli, S.; Ragionieri, L.; Ravanetti, F.; Botti, M.; Gazza, F.; Cacchioli, A.; Di Lecce, R.; et al. Orexin A in swine corpus luteum. Domest. Anim. Endocrinol. 2018, 64, 38-48. [CrossRef]

17. Ciccimarra, R.; Bussolati, S.; Grasselli, F.; Grolli, S.; Ragionieri, L.; Ravanetti, F.; Botti, M.; Gazza, F.; Cacchioli, A.; Di Lecce, R.; et al. Orexin system in swine ovarian follicles. Domest. Anim. Endocrinol. 2018, 62, 49-59. [CrossRef] [PubMed] 
18. Kaminski, T.; Smolinska, N.; Kiezun, M.; Dobrzyn, K.; Szeszko, K.; Maleszka, A. Effect of orexin B on CYP17A1 and CYP19A3 expression and oestradiol, oestrone and testosterone secretion in the porcine uterus during early pregnancy and the oestrous cycle. Animal 2018, 12, 1921-1932. [CrossRef]

19. Kisielewska, K.; Rytelewska, E.; Gudelska, M.; Kiezun, M.; Dobrzyn, K.; Szeszko, K.; Bors, K.; Wyrebek, J.; Kaminski, T.; Smolinska, $\mathrm{N}$. The effect of orexin B on steroidogenic acute regulatory protein, P450 side-chain cleavage enzyme, and 3 beta-hydroxysteroid dehydrogenase gene expression, and progesterone and androstenedione secretion by the porcine uterus during early pregnancy and the estrous cycle. J. Anim. Sci. 2019, 97, 851-864. [PubMed]

20. Liguori, G.; Tafuri, S.; Miyoshi, C.; Yanagisawa, M.; Squillacioti, C.; De Pasquale, V.; Mirabella, N.; Vittoria, A.; Costagliola, A. Localization of orexin B and orexin-2 receptor in the rat epididymis. Acta Histochem. 2018, 120, 292-297. [CrossRef]

21. Cataldi, N.I.; Lux-Lantos, V.A.; Libertun, C. Effects of orexins A and B on expression of orexin receptors and progesterone release in luteal and granulosa ovarian cells. Regul. Pept. 2012, 178, 56-63. [CrossRef]

22. Basini, G.; Bussolati, S.; Ciccimarra, R.; Grasselli, F. Melatonin potentially acts directly on swine ovary by modulating granulosa cell function and angiogenesis. Reprod. Fertil. Dev. 2017, 29, 2305-2312. [CrossRef] [PubMed]

23. Basini, G.; Bussolati, S.; Santini, S.E.; Grasselli, F. Sanguinarine inhibits VEGF-induced angiogenesis in a fibrin gel matrix. BioFactors 2007, 29, 11-18. [CrossRef]

24. Babalola, G.O.; Shapiro, B.H. Correlation of follicular steroid hormone profiles with ovarian cyclicity in sows. Reproduction 1988, 84, 79-87. [CrossRef]

25. Akins, E.L.; Morrissette, M.C. Gross ovarian changes during estrous cycle of swine. Am. J. Vet. Res. 1968, 29, 1953-1957.

26. Dall'Aglio, C.; Zannoni, A.; Forni, M.; Bacci, M.L.; Ceccarelli, P.; Boiti, C. Orexin system expression in the gastrointestinal tract of pigs. Res. Vet. Sci. 2013, 95, 8-14. [CrossRef]

27. Grasselli, F.; Basini, G.; Tirelli, M.; Cavalli, V.; Bussolati, S.; Tamanini, C. Angiogenic activity of porcine granulosa cells cocultured with endothelial cells in a microcarrier-based three-dimensional fibrin gel. J. Physiol. Pharmacol. 2003, 54, 361-370. [PubMed]

28. Basini, G.; Baioni, L.; Bussolati, S.; Grolli, S.; Grasselli, F. Prolactin is a potential physiological modulator of swine ovarian follicle function. Regul. Pept. 2014, 189, 22-30. [CrossRef] [PubMed]

29. Basini, G.; Ragionieri, L.; Bussolati, S.; Di Lecce, R.; Cacchioli, A.; Dettin, M.; Cantoni, A.M.; Grolli, S.; La Bella, O.; Zamuner, A.; et al. Expression and function of the stromal cell-derived factor-1 (SDF-1) and CXC chemokine receptor 4 (CXCR4) in the swine ovarian follicle. Domest. Anim. Endocrinol. 2020, 71, 106404. [CrossRef] [PubMed]

30. Foxcroft, G.R.; Hunter, M.G. Basic physiology of follicular maturation in the pig. J. Reprod. Fertil. Suppl. 1985, 33, 1-19.

31. Kaminski, T.; Nitkiewicz, A.; Smolinska, N. Changes in plasma orexinA and orexin B concentrations during the oestrous cycle of the pig. Peptides 2013, 39, 175-177.

32. Basini, G.; Bussolati, S.; Iannarelli, M.; Ragionieri, L.; Grolli, S.; Ramoni, R.; Dodi, A.; Gazza, F.; Grasselli, F. The myokine irisin: Localization and effects in swine late medium and large antral ovarian follicle. Domest. Anim. Endocrinol. 2021, $74,106576$. [CrossRef] [PubMed]

33. Basini, G.; Tamanini, C. Selenium stimulates estradiol production in bovine granulosa cells: Possible involvement of nitric oxide. Domest. Anim. Endocrinol. 2000, 18, 1-17. [CrossRef]

34. Pacentra, A.; Grasselli, F.; Bussolati, S.; Grolli, S.; Di Lecce, R.; Cantoni, A.M.; Basini, G. The effect of pathogen-associated molecular patterns on the swine granulosa cells. Theriogenology 2020, 145, 207-216. [CrossRef]

35. Basini, G.; Bussolati, S.; Baioni, L.; Grasselli, F. Gossypol, a polyphenolic aldehyde from cotton plant, interferes with swine granulosa cell function. Domest. Anim. Endocrinol. 2009, 37, 30-36. [CrossRef]

36. Basini, G.; Baioni, L.; Bussolati, S.; Grolli, S.; Kramer, L.H.; Wagner, G.F.; Grasselli, F. Expression and localization of stanniocalcin 1 in swine ovary. Gen. Comp. Endocrinol. 2010, 166, 404-408. [CrossRef]

37. Butcher, J.T.; Tressel, S.; Johnson, T.; Turner, D.; Sorescu, G.; Jo, H.; Nerem, R.M. Transcriptional Profiles of Valvular and Vascular Endothelial Cells Reveal Phenotypic Differences. Arterioscler. Thromb. Vasc. Biol. 2006, 26, 69-77. [CrossRef] [PubMed]

38. Basini, G.; Bussolati, S.; Santini, S.E.; Bianchi, F.; Careri, M.; Mangia, A.; Musci, M.; Grasselli, F. Hydroxyestrogens inhibit angiogenesis in swine ovarian follicles. J. Endocrinol. 2008, 199, 127-135. [CrossRef]

39. Russell, S.H.; Small, C.J.; Kennedy, A.R.; Stanley, S.A.; Seth, A.; Murphy, K.G.; Taheri, S.; Ghatei, M.A.; Bloom, S.R. Orexin A interactions in the hypothalamus-pituitary-gonadal axis. Endocrinology 2001, 142, 5294-5302. [CrossRef] [PubMed]

40. Kok, S.W.; Roelfsema, F.; Overeem, S.; Lammers, G.J.; Frölich, M.; Meinders, A.E.; Pijl, H. Pulsatile LH release is diminished, whereas FSH secretion is normal, in hypocretin-deficient narcoleptic men. Am. J. Physiol. Endocrinol. Metab. 2004, 287, E630-E636. [CrossRef] [PubMed]

41. Barb, C.R.; Matteri, R. Orexin-B modulates luteinizing hormone and growth hormone secretion from porcine pituitary cells in culture. Domest. Anim. Endocrinol. 2005, 28, 331-337. [CrossRef]

42. Scammell, T.E.; Winrow, C.J. Orexin receptors: Pharmacology and therapeutic opportunities. Annu. Rev. Pharmacol. Toxicol. 2011, 51, 243-266. [CrossRef]

43. Sokołowska, P.; Urbańska, A.; Biegańska, K.; Wagner, W.; Ciszewski, W.; Namiecińska, M.; Zawilska, J.B. Orexins protect neuronal cell cultures against hypoxic stress: An involvement of Akt signaling. J. Mol. Neurosci. 2014, 52, 48-55. [CrossRef]

44. Couvineau, A.; Voisin, T.; Nicole, P.; Gratio, V.; Abad, C.; Tan, Y.V. Orexins as Novel Therapeutic Targets in Inflammatory and Neurodegenerative Diseases. Front. Endocrinol. 2019, 22, 709. [CrossRef] [PubMed] 
45. Basini, G.; Grasselli, F. Nitric oxide in follicle development and oocyte competence. Reproduction 2015, 150, R1-R9. [CrossRef] [PubMed]

46. Zhang, C.; Abdukerim, M.; Abilailieti, M.; Tang, L.; Ling, Y.; Pan, S. The protective effects of orexin a against high glucose-induced activation of NLRP3 inflammasome in human vascular endothelial cells. Arch. Biochem. Biophys. 2019, 672, 108052. [CrossRef] [PubMed]

47. Kim, Y.W.; Byzova, T.V. Oxidative stress in angiogenesis and vascular disease. Blood 2014, 123, 625-631. [CrossRef]

48. Johren, O.; Neidert, S.J.; Kummer, M.; Dendorfer, A.; Dominiak, P. Prepro-orexin and orexin receptor mRNAs are differentially expressed in peripheral tissues of male and female rats. Endocrinology 2001, 142, 3324-3331. [CrossRef] [PubMed]

49. Kim, M.K.; Park, H.J.; Kim, S.R.; Choi, Y.K.; Shin, H.K.; Jeon, J.H.; Jang, H.O.; Yun, I.; Bae, S.K.; Bae, M.K. Angiogenic role of orexin-A via the activation of extracellular signal-regulated kinase in endothelial cells. Biochem. Biophys. Res. Commun. 2010, 403, 59-65. [CrossRef]

50. Heinonen, M.V.; Purhonen, A.K.; Mäkelä, K.A.; Herzig, K.H. Functions of orexins in peripheral tissues. Acta Physiol. 2008, 192, 471-485. [CrossRef]

51. Kim, M.K.; Park, H.J.; Kim, S.R.; Choi, Y.K.; Bae, S.K.; Bae, M.K. Involvement of Heme Oxygenase-1 in Orexin-A-induced Angiogenesis in Vascular Endothelial Cells. Korean J. Physiol. Pharmacol. 2015, 19, 327-334. [CrossRef] [PubMed]

52. Berisha, B.; Schams, D.; Rodler, D.; Pfaffl, M.W. Angiogenesis in The Ovary-The Most Important Regulatory Event for Follicle and Corpus Luteum Development and Function in Cow-An Overview. Anat. Histol. Embryol. 2016, 45, 124-130. [CrossRef] [PubMed] 